Alexander PSHINKO, Liudmila GOLOVKOVA, Viktoriia KOLOMIIETS, Liliia DOBRYK

\title{
COSTS OF THE HUMAN CAPITAL AND DEVELOPMENT OF THE SOCIAL POTENTIAL IN ACCOUNTING SYSTEM FOR CENTRAL AND EASTERN EUROPE
}

\begin{abstract}
Nowadays, human capital and social potential become the most valuable resource for the harmonious development of the national economy. Expenditure on human capital and social development should occupy a significant part in the state budgets of countries. Therefore, accounting of such expenses is extremely important.

(C) Alexander Pshinko, Liudmila Golovkova, Viktoriia Kolomiiets, Liliia Dobryk, 2020.

Pshinko Alexander, Doctor of Technical Sciences, Professor, Rector of the Dnipro National University of Railway Transport named after Academician V. Lazaryan, Ukraine. ORCID: https://orcid.org/00000002-1598-2970 Email: dnuzt@diit.edu.ua.

Golovkova Liudmila, Doctor of Economics, Professor, Head of Finance and Economic Security Department, Dnipro National University of Railway Transport named after Academician V. Lazaryan, Ukraine. ORCID: https://orcid.org/0000-0001-5473-6644 Email: g.liudmila22@gmail.com.

Kolomiiets Viktoriia, PhD in Economics, Associate Professor, doctoral student at Finance and Economic Security Department, Dnipro National University of Railway Transport named after Academician V. Lazaryan, Ukraine. ORCID: https://orcid.org/0000-0003-3427-8986 Email: vik2005vik@meta.ua. Dobryk Liliia, PhD in Economics, Associate Professor, Finance and Economic Security Department, Dnipro National University of Railway Transport named after Academician V. Lazaryan, Ukraine. ORCID: https://orcid.org/0000-0002-3853-9285 Email: liliadobrik@gmail.com.
\end{abstract}


The purpose of the study is to reveal the possibility of accounting for expenditures on the human capital and social potential development in the accounting system of the Central and Eastern Europe, provide recommendations for the current accounting system.

The research revealed the plurality and ambiguity of the interpretation for the categories «human capital» and «social potential». The regulatory and legislative uncertainty complicates the accounting of the human capital costs and development of the social potential. These categories must be defined by law. As per normative and methodological basis for the accounting of the human capital, it would be better to apply the International Financial Reporting Standards.

The absence or misrepresentation of information about available human capital are contrary to IFRS requirements and reduces or exaggerates the value of the organization. It is offered in IFRS, to provide a comprehensive accounting of the cost for the human capital and developing social capacity.

The budget of the Central and Eastern European countries includes only the costs of social protection, health, education, recreation, culture, religion. After the budget analysis was conducted, the authors proposed to develop new objects of accounting (human capital, social potential), accounting standards for it. A part of the GDP expenses should be directed to the financing of the human capital expenditures and social potential development.

\section{Key words:}

Human capital, social potential, IFRS, accounting.

JEL: E24, G41, H83.

\section{Introduction}

Human capital is one of the main sources of interest in the study of economic growth in Central and Eastern Europe. It is positioned as the most valuable resource of the economy. At the same time, an integral part of enriching human capital is the development of the social potential. The corresponding social potential becomes a prerequisite for the harmonious development of national economy. 
184 Alexander Pshinko, Liudmila Golovkova, Viktoriia Kolomiiets, Liliia Dobryk

Costs of the human capital and development of the social potential in accounting system for Central and Eastern Europe

The creation of favorable conditions for the development of society is an extremely difficult problem. It repeatedly worsens in the territories with unstable political, economic and social situation (Kvilinskyi, 2017), meaning a number of countries in Central and Eastern Europe, including Ukraine. Spending on human capital and the development of social potential should occupy an important place in the state budget of countries and the budget of separate economic entities. It is necessary to improve the accounting of the distribution of state expenditures in these directions of economic policy. There are no recommendations about specific mechanisms, assessment systems that can be used by institutions and organizations, regulatory authorities to analyze the effectiveness of the use of budgetary funds in general (Kurganskaya, 2017), and which are used for the human capital and social development at that moment.

The interaction between human capital and human resources, development of the social potential, the capital and the financial market has a positive impact on the economic growth of the country. All these components are important and complementary factors of this process (Mahmood, 2018). Further improvement of the quality is possible only through spending on the human capital and social development. The impact of human capital on economic development is observed not only for individual countries, but also for entire regions (Siddiqui, 2017). Economic opportunities play a constructive role in human capital for support of the growth phenomena (Ali, 2018).

According to the above-mentioned factors, we should note the relevance of accounting for human capital costs and the development of social potential for each country.

However, global economic research of human capital and social potential has concerned mostly theoretical issues and is limited in practical use. At the same time, both human and social capital require significant financial investments. Financing of the human capital and social potential at the level of public finance management has not been clearly resolved to date. The expenses of the state budgets in Central and Eastern Europe include the individual components of human and social capital costs and do not consider "costs of human capital», "costs for development of social capacities» in a comprehensive manner. Taking into consideration this provision, there is no accounting for the human capital and social development expenditures.

The aim of the study is to reveal the necessity, possibility of accounting of human capital and social potential development in the accounting systems of Central and Eastern Europe, and to provide practical recommendations for accounting of the above - mentioned expenses.

This investigation sets and solves the following tasks: 
- exploring expenditures of Central and Eastern European countries on human capital, taking into account the updated content of the concept of human capital, social potential or their components;

- analyzing the existing accounting of human capital and its components in International Accounting Standards, Central and Eastern Europe, and Ukraine;

- considering the actual accounting of expenditures on human capital;

- assessing the possibilities of constructing cost accounting for the development of social potential;

- characterizing the actual expenses of Central and Eastern European countries on human capital and social potential.

The results of this theoretical and empirical research can be used at the level of methodological developments and applied recommendations for the Ministries of Finance for these countries. The results of the study are intended for use during the processing of programs of socio-economic development of Central and Eastern Europe, the preparation of the draft laws and regulations about the reproduction of the human capital and development of the social potential. The theoretical research should be the basis for the formation of public policy in the system of public finance management for the national economy, the development of human capital, development strategy, social potential, the basis for further scientific research.

\section{Literature review}

Scientific thought over the past two centuries has paid close attention to the identification of the human capital and social potential's role in ensuring the effective functioning of the economic system of a country.

The formation of the theory of human capital is associated with the works of I. Fisher (1930), but in some works can be traced to earlier studies of human capital. In the writings of D. Nicholson (1891) the part of the capital that lies in people, and not money, the earth, or equipment.

The fundamental theoretical basis for the formation of the General classical theory of capital is found in A. Smith's works (1976).

The authors of the most significant research on the concept of human capital include G. Becker (1964), D. Mincer (1974; 1981) and T. Schulz (1961).

A more profound definition of human capital and social potential are proposed by modern researchers like N. Bontis, N. Dragonetti, K. Jacobsen, G. Rus 
186 Alexander Pshinko, Liudmila Golovkova, Viktoriia Kolomiiets, Liliia Dobryk

Costs of the human capital and development of the social potential in accounting system for Central and Eastern Europe

(1999), E. Pelinescu (2015), V. Kolomiiets, L. Golovkova (2017), N. Simchenko, G. Zhaldak (2014).

E. Glaeser (1993) summarized the theory behind the term «social capital». R. Putnam (1996) defined social capital for the first time, which started the social potential theory. Social factors of society development were studied by Kvilinskyi, A. Mieshkov, I. Bondaryeva (2017), S. Sardak, O. Belsky, A. Simakhova (2017).

The concept of human capital competence management was formulated in the early seventies of the $20^{\text {th }}$ century, when one of the classics of political economy D. McClelland (1973) noted that the best predictor of the candidate's success is his competence and ability.

Accounting of human and social capital as part of intangible capital of a company were explored by modern experts, such as K. Precob, M. Mironiuc (2016), V. Boronos, I. Plikus, V. Aleksandrov (2016), S.-C. Necula (2017), K. Payak, B. Kaminska, O. Kvilinskyi (2016).

\section{Methodology}

The systematic approach was the methodological basis of the study. The theoretical basis of the study is comprised of the provisions of classical and institutional theory, the theory of human capital. A set of methods were used to achieve the research goals and implementation of the tasks, including theoretical research, economic and statistical methods and analysis of empirical data.

\section{Results and Discussion}

\subsection{Understanding the economic essence of human capital and social potential for accounting purposes}

The spending on human capital and social capacity-building should be sufficiently strong and occupy a significant share in the country's budget for the harmonious development of the country.

Analytical data on material costs of human capital, expressed in monetary terms are widely used in methods of assessing human capital. 
Each country determines the priority of expenditures, investments and calculates their effects. A number of researchers consider investment in human capital an effective direction of possible development scenarios of Central and Eastern Europe (Radyeva, 2017; Rekun, 2015; Tkach, 2013).

At the same time, the introduction of a single full-featured software and the creation of an information and accounting system will facilitate the management needs at the country level (Kurganskaya, 2017).

In this case, there is a need to build a transparent system of accounting for human capital and social potential. Such factors as ambiguity of interpretations of the categorical apparatus and legislative uncertainty of accounting and economic terms, different approach to the interpretation of the applied categories of the accounting, economic, managerial, business points of view have always impeded a clear accounting.

These factors have long complicated the accounting process of such wellestablished concepts as fixed assets, profit, financial results, goodwill, biological assets, intangible assets and a number of less certain categories, which include human capital and social potential. The constant process of changing the accounting content and economic essence of accounting instruments can be justified by the changing institutional environment of a number of countries, technological progress that changes the conditions for the existence of production systems, transition to a new economy - the «knowledge economy» and, finally, natural social evolution.

The introduction of International Accounting Standards with the gradual replacement and updating of their International Financial Reporting Standards (Required IFRS Standards 2018, 2018) has contributed to the further standardization of a number of definitions in accounting, especially old categories.

The formation of the concepts of «human capital» and «accumulation of social potential» has been going on for the last 60-70 years and is still going on. A number of scientists from all over the world are actively searching for the essence of the above-mentioned categories and their content. It can be argued that these concepts are at the peak of their relevance for the global scientific thought.

However, while such searches lead to positive development of society from the point of view of economists, for accountants such a multitude of interpretations only adds new complications in the established accounting.

The simplified definition of human capital is its interpretation as a set of knowledge, abilities, experience, skills, and education. Their varied accumulation by one person explains the different ability of owners to generate material resources, money, technology and intangible assets.

G. Becker and T. Shultz, the founders of this theoretical direction and global concept of human capital, provided the basic definitions of human capital. 
188 Alexander Pshinko, Liudmila Golovkova, Viktoriia Kolomiiets, Liliia Dobryk

Costs of the human capital and development of the social potential in accounting system for Central and Eastern Europe

The human capital is a stock of knowledge, skills, motivations, investments into which become education, experience, health, mobility, and awareness (Becker, 1964).

Human capital is also considered as a set of all inborn and acquired human abilities. Properties that are valuable and can be developed through appropriate investments are recognized as human capital (T. Shultz, 1961).

The latest macroeconomic studies determine that an individual and their intellectual potential and abilities is a strategic resource that can be formed, developed, and which becomes a potentially new source of competitiveness of both the individual and enterprises, the national economy, and the world economy.

Social capital is comprised of the following components: education, health, social infrastructure, social hierarchy, demographic trends, criminal and military risks (Kvilinskyi, 2017).

In recent studies on EU countries, human capital development is associated with social potential and is considered in three directions, namely: the social potential of human capital, the pace of innovative development of human capital and the potential of human capital development. Now, the social potential of human capital as a mathematical variable characterizes the achieved state of human capital development in the country. The coefficient of innovative development of human capital is used to describe the creativity of human capital in the country, and the potential of human capital development describes the prerequisites for the development of human capital (Vaitkevičius, 2015). In these interpretations it is difficult to determine the accounting content, and therefore using them for the purpose of accounting is impossible.

Conclusion 1. The multiplicity and ambiguity of the interpretation of the «human capital» and "social potential» categories, their regulatory and legislative uncertainty complicate the accounting of human capital costs and the development of social potential.

\subsection{Review of the international normative documents}

Accounting of human capital is a relatively new direction in the financial system. There is a need for access to financial, accounting information for users due to globalization, international cooperation between countries in different markets. Such information is currently generated in the accounting systems of each individual country. However, it cannot be applied in comparative international studies, because the accounting in each country has individual characteristics associated with political, economic, legislative conditions. It is useful to examine 
international regulations that may be used for human capital accounting purposes, for appraisal and comparison of human capital studies.

These requirements are met by the International Financial Reporting Standards (IFRS, 2018), previously known as International Accounting Standards (IAS), developed by the International Accounting Standards Board (IASB). Therefore, we propose to use International Financial Reporting Standards as the normative methodological basis at the international level in this study. According to the updated document Conceptual Framework for Financial Reporting (2018), the International Accounting Standards Board seeks to reduce differences in accounting and reporting of different countries by harmonizing the regulatory provisions, accounting standards and procedures related to the preparation and presentation of financial statements. The board considers that further harmonization of everything can be achieved by focusing on financial statements that are prepared to provide information useful for economic decision-making. The board considers that the financial statements prepared for this purpose meet general needs of the majority of users. This is explained by the fact that almost all users make economic decisions, for example, in order to: a) determine when to buy, hold or sell investment capital; b) assess the management and accountability of management personnel; $\mathrm{c}$ ) assess the ability of the business entity to pay wages and provide other payments to its employees; d) assess the security of the amounts owed to the business entity; d) determine the tax policy; e) determine the amount of profit and the amount of dividends to be distributed; e) prepare and use national income statistics; g) regulate the activities of business entities.

Conclusion 2. It is advisable to apply International Financial Reporting Standards as a normative and methodological basis for accounting of human capital at the international level.

\subsection{Human capital in International Financial Reporting Standards}

This subsection of the study examines all mentions connected to the human capital in the IFRS.

Conceptual Framework for Financial Reporting (2018) specified that "....information is needed about .... and how efficiently and effectively the management has discharged its responsibilities to use the entity's economic resources".

The IASB also gives examples of the duties of managerial staff, which, in our opinion, can be attributed to the functions of human capital (Required IFRS Standards, 2018): 
190 Alexander Pshinko, Liudmila Golovkova, Viktoriia Kolomiiets, Liliia Dobryk

Costs of the human capital and development of the social potential in accounting system for Central and Eastern Europe

- protection of resources of a business entity from adverse effects of economic factors;

- ensuring the business entity's compliance with the relevant laws and contracts.

The IFRS repeatedly emphasizes the importance of the performance quality of the managerial duties (Required IFRS Standards, 2018). We believe that the unique human capital is the basis for fulfilling these obligations, and it must be accounted for and considered in the international financial reporting.

Conclusion 3: information on the execution of managerial personnel's duties is needed. It cannot be estimated by objective indicators or by direct arithmetic calculation. Therefore, in this case, expert assessment is necessary for management decision-making and fair value assessment for accounting purposes.

Necula S.-C. (2017) noted the need to assess the fair value in terms of economic and financial profitability for the formation of an objective information system of management.

Accumulation of knowledge, professional and communication skills, their implementation in practice lead to an increase and accumulation of human capital of a business entity and the national economy as a whole.

Thus, the quality of performance of their duties by management personnel becomes part of human capital.

The next argument in favor of accounting of human capital is the fact that human capital affects the competitiveness of a business entity (the quality of human capital can be a significant or unique competitive advantage) and the value of the company when selling. The above correlates with the requirements of IFRS on the relevance of the information (Required IFRS Standards, 2018): «Information is relevant if its omission or incorrect presentation could influence decisions made by users on the basis of financial information about a specific reporting entity».

V. Boronos, I. Plikus, V. Aleksandrov (2016) calculated the loss of profits from intangible assets for the owners of a particular enterprise. They determined that the reason for the discrepancy between the value of equity calculated according to the balance sheet and its market value is the presence of hidden (offbalance) capital, which is embodied in the available intangible facts and the most important of which are human capital and social potential.

Given this point, the lack or misrepresentation of information on available human capital is contrary to the requirements of IFRS and reduces or exaggerates the value of the business.

IFRS considers the costs of wages, social security, health protection, labor protection, education (Required IFRS Standards, 2018). However, the existence 
of such important components, the support and financing of good mental health, creative abilities, and intellectual potential are not defined.

Nevertheless, human capital affects the competitiveness of a business entity and the market value of a company. Human capital and social potential are important and complementary indicators for ensuring and enhancing a country's economic growth (Mahmood, 2018). The above meet the requirements of IFRS about the relevance of information (Required IFRS Standards, 2018). National accounting does not consider all components of human capital. Therefore, it can be argued that the cost of human capital is not reflected in full, and is distorted.

Conclusion 4: IFRS must provide comprehensive accounting of expenditures on human capital, including the maintenance of good mental health, the presence of creative abilities, intellectual potential.

The next step in the regulation of accounting was the creation of the International Integrated Reporting Council (IIRC) «International Integrated Reporting Framework» (2013). For the first time, a regulatory and legislative document noted the definition of «human capital», «social and relationship capital», and «intellectual capital».

However, the International Integrated Reporting Framework determined that these types of capital do not necessarily have to be included in Integrated Reporting (2013). The organization itself determines the need to reflect these types of capital, depending on the degree of its interaction with this type of capital. Thus, the organization has another opportunity to reduce or increase the value of the company, further proving our preliminary findings.

\subsection{Expenses of the Central and Eastern European countries on human capital and social potential}

Research on expenses of the Central and Eastern European countries on human capital and social potential is based on data from the European Commission (Eurostat, 2018). The countries of Central and Eastern Europe include Estonia, Latvia, Lithuania, Poland, Germany, the Czech Republic, Slovakia, Hungary, Romania, Bulgaria, Slovenia, Croatia, Albania, Montenegro, Serbia, Macedonia, Bosnia and Herzegovina, and Kosovo.

The analysis of the CEE countries' budgets showed that the budget expenditures attributed to the expenditure on human capital and the development of social potential take into account only social protection costs, health care costs, education costs, spending on recreation, culture and religion. Other possi- 
ble directions are not taken into account, and in most cases, such expenditures are not provided by the state budgets.

On average, in the European Union countries the costs were: social protection - $19.9 \%$ of the annual GDP, health protection - $7.3 \%$ of GDP, education $-5.3 \%$ of GDP, leisure, culture and religion $-1.1 \%$ of GDP. Data vary considerably on selected countries. For example, public spending on recreation, culture and religion was the largest in the Czech Republic (2.7\% GDP).

More than half of the European Union expenditure was allocated to social protection and health, which accounted for 19.9 percent and 7.3 percent of GDP, respectively, considering that all expenditure amounted to 49.4 percent of GDP.

In general, social protection is the most important function of public expenditure and provides for retirement benefits, retirement care, sick leave and disability payments, family and children. The cost of pensions is at least $2 / 3$ of social expenditure in Bulgaria and Latvia. The lowest rates of retirement benefits (1/3 of social protection) are in Croatia and Norway, due to the existence of non-state pension funds. The costs of sick leave and disability payments in social protection are the second biggest, amounting to about 20 percent in Lithuania and Croatia.

Health expenditure is the second largest in the total budget of the European Union countries and is about €948 billion, or $7.3 \%$ of GDP. The highest share is found in Croatia (9.2\% of GDP or $20 \%$ of total public expenditure), the lowest - in Romania (3.1\% of GDP).

Education was allocated $5.3 \%$ of GDP of the European Union, which represents $€ 680$ billion. The lowest indicator was recorded in Romania (3.0\% of GDP), Bulgaria (3.5\% of GDP) and Slovakia (3.9\% of GDP). The largest amount of public expenditure in education was in Estonia (16.2\% of total expenditure), followed by Lithuania (15.5\% of GDP) and Latvia (15.0\% of GDP).

For comparison, the costs of human capital in Ukraine were: social protection expenditure $-4.9 \%$ of GDP, expenditure on education - $6 \%$ of GDP, spending on pensions $-4.7 \%$ of GDP, expenditure on health $-3.4 \%$, expenditure on culture and sport $-0.8 \%$ of GDP (Price of the State, 2018).

Conclusion 5: the analysis of the CEE countries' budgets showed that the budget expenditures attributed to the expenditure on human capital and the development of social potential take into account only social protection costs, health care costs, education costs, spending on recreation, culture and religion. Other possible directions are not taken into account, and in most cases, such expenditures are not provided by the state budgets. Therefore, the development of new accounting categories (human capital, social potential), the development of accounting standards for them, the formation of a system of expenditure on human capital and the development of social potential are required. We consider the need in each country of Central and Eastern Europe to allocate a portion of pub- 
lic spending on human capital and developing social capacity to be urgent. The end result of the proposed process of setting up the accounting system should be a harmonized accounting of human capital costs and the development of the social potential of each country of Central and Eastern Europe.

\section{General conclusions}

The conducted research made it possible to draw the following conclusions. The multiplicity and ambiguity of the interpretation of the categories «human capital», "social potential», legislative and regulatory uncertainty make it difficult to account for the costs of human capital and the development of social potential. Legislative definition of these accounting categories is required. International Financial Reporting Standards should be used as a normative and methodological basis for accounting of human capital at the international level.

Lack or misrepresentation of information about available human capital is contrary to IFRS requirements and reduces or overestimates the cost of an organization. We propose that IFRS should provide comprehensive accounting of human capital costs, including support for good mental health, creative abilities, intellectual potential.

The analysis showed that the budget of the CEE countries includes only expenditure on social protection, health, education, recreation, culture and religion. Other possible areas are not taken into account, and in most cases such expenses are not provided for by national budgets. Therefore, it is necessary to develop new accounting categories (human capital, social potential) and accounting standards for them. Part of the public expenditure also should be aimed at financing human capital costs and the development of social potential.

We insist that every country in Central and Eastern Europe needs to allocate part of its GDP expenditures to finance human capital and social potential. This is an urgent need. The end result of the process proposed in the study is a harmonized system of accounting of expenditures on human capital and the development of the social potential of Central and Eastern Europe.

The direct effect can be seen not only in the redistribution of state funding and improvement of accounting, but also in increasing human capital and indicators of the growth of the social potential of each state in Central and Eastern Europe. Accordingly, we expect the legislative branches to introduce accounting for expenditures on human capital and the development of social potential into the state budgets of their countries, and create a system of state financing of such expenditures. 


\section{References}

1. Ali M., Egbetokun A., Memon M. (2018). Human capital, social capabilities and economic growth. Economies, 6(2), pp. 1-18, Retrieved from: https://doi.org/10.3390/economies6010002.

2. Kvilinskyi O., Mieshkov A., Bondaryeva I. (2017). Investigation of the social factors of development of society in the territories with transforming environment. Research Papers in Economics and Finance, 2(2), pp. 13-19, Retrieved from: http://ref.ue.poznan.pl/index.php/REF/article/view/36.

3. Kurganskaya E. (2017). The System of the Treasury in Ukraine. Actuality and prospects of development. Research Papers in Economics and Finance, 2(3), pp. 15-22, Retrieved from: http://dx.doi.org/10.18559/ref.2017.3.2.

4. Mahmood H., Alkahtani N. (2018). Human resource, financial market development and economic growth in Saudi Arabia: a role of human capital. Economic Annals-XXI, 169(1-2), pp. 31-34, Retrieved from: https://doi.org/ 10.21003/ea.V169-06.

5. Siddiqui A., Rehman A. (2017). The Human Capital and Economic Growth Nexus: in East and South Asia. Applied Economics, 49 (28), pp. 2697-2710, Retrieved from: https://doi.org/10.1080/00036846.2016.1245841.

6. Fisher I. (1930). The application of mathematics to the social sciences. Bull. Amer. Math. Soc., 36 (4), pp. 225-243, Retrieved from: 10.1090/s0002-99041930-04919-8.

7. Nicholson J. (1891). The Living Capital of the United Kingdom. Economic Journal, 1, pp. 95-107.

8. Smith A. (1976). An Inquiry into the Nature and Causes of the Wealth of Nations. The Glasgow Edition of the Works and Correspondence of Adam Smith, Vol. II, edited by R.H. Campbell and A.S. Skinner. Oxford University Press, Retrieved from: https://www.ibiblio.org/ml/libri/s/SmithA_ WealthNations_p.pdf.

9. Becker G. S. (1964). Human Capital. N.Y.: Columbia University Press.

10. Mincer J. (1974). Progress in Human Capital Analysis of the Distribution of Earnings. Stanford: Junipero Serra Blvd.

11. Mincer J. (1981). Human Capital and Economic Growth. NBER Working Paper, 803, Retrieved from: http://www.nber.org/papers/w0803.pdf.

12. Bontis N., Dragonetti N., Jacobsen K., Roos G. (1999). The Knowledge Toolbox: A Review of Tools Available to Measure and Manage Intangible Resources. European Management Journal, 17(4), pp. 391-402. 
13. Schulz T. W. (1961). Investment in Human Capital. American Economic Review, 51, pp. 1-17.

14. Pelinescu E. (2015). The Impact of Human Capital on Economic Growth. Procedia Economics and Finance, 22, pp. 184-190, Retrieved from: https://doi.org/10.1016/S2212-5671(15)00258-0.

15. Kolomiiets V., Golovkova L. (2017). The institutional content of the human capital of the national economy. Baltic Journal of Economic Studies, 3(5), pp. 289-293, Retrieved from: http://www.baltijapublishing.Iv/index.php/ issue/article/view/297.

16. Simchenko N. O., Zhaldak G. P. (2014). Scientific approaches to assessment of social innovations at industrial enterprises. Actual Problems of Economics, 1, pp. 376-382, Retrieved from: http://nbuv.gov.ua/UJRN/ape_2014_1_46.

17. Sardak S., Bilska O., Simakhova A. (2017). Potential of economy socialisation in the context of globalisation. Economic Annals-XXI, 164(3-4), pp. 4-8, Retrieved from: https://doi.org/10.21003/ea.V164-01.

18. McClelland D. (1973). Testing for Competence Rather Than for «Intelligence». American Psychologist, January, pp. 1-14.

19. Precob C., Mironiuc M. (2016). The Influence of Reporting Intangible Capital on the Performance of Romanian Companies. The Audit Financiar journal, 1(133), pp. 103-114, Retrieved from: http://dx.doi.org/10.20869/AUDITF/ 2016/133/103.

20. Boronos V., Plikus I., Aleksandrov V. (2016). Financial and accounting approaches to definition of the intangible factors impact on the value of the company. Economic Annals-XXI, 160(7-8), pp. 121-125, Retrieved from: http://soskin.info/userfiles/file/Economic-Annals-pdf/DOI/ea-V160-24.pdf

21. Necula S.-C. (2017). Accounting decisions from the perspective of profitability. Economic Annals-XXI, 166(7-8), pp. 72-75, Retrieved from: https://doi.org/10.21003/ea.V166-14.

22. Pająk K., Kamińska B., Kvilinskyi O. (2016). Modern trends of financial sector development under the virtual regionalization conditions, Financial And Credit Activity. Problems Of Theory And Practice, 2(21), pp. 204-217, Retrieved from: http://fkd.org.ua/article/view/91052/92128.

23. Radyeva M. N., Porokhnia V. M., Kuznetsov V. I. (2017). Modeling the Impact of Intellectual Capital on Macroeconomic Processes in the State. State and Regions. Series: Economics and Entrepreneurship, 2, pp. 22-25. (in Ukrainian)

24. Rekun I. (2015). Personnel management in the system of economic security of the railway transport company. Economics and State: International Scientific and Practical Journal, 11, pp. 28-32. (in Ukrainian) 
196 Alexander Pshinko, Liudmila Golovkova, Viktoría Kolomiiets, Liliia Dohryk Costs of the human capital and development of the social potential in accounting system for Central and Eastern Europe

25. Tkach A. A. (2013). Formation of the institutional paradigm of economic theory. Bulletin of International Nobel Economic Forum, 1, pp. 329-334. (in Ukrainian)

26. Required IFRS Standards 2018. (2018). Retrieved from: https://www.ifrs.org/ issued-standards/list-of-standards/

27. Vaitkevičius S., Čiutienė R., Meilienė E., Savanevičienė A. (2015). Typology of Human Capital Development in EU Countries. Procedia Economics and Finance, 23, pp. 1641-1648, Retrieved from: https://doi.org/10.1016/S22125671(15)00520-1.

28. Conceptual Framework for Financial Reporting (Conceptual Framework). (2018). Retrieved from: https://www.ifrs.org/-/media/project/conceptualframework/fact-sheet-project-summary-and-feedback-statement/conceptualframework-project-summary.pdf.

29. International Integrated Reporting Framework. (2013). International Integrated Reporting Council («IIRC»). Retrieved from: http://integratedreporting.org/ resource/international-ir-framework/

30. Price of the state. (2018). Retrieved from: http://cost.ua/budget/expenditure/

31. Glaeser E. W. (1993). The Formation of Social Capital. OECD Conference Papers. Chicago-L, Retrieved from: http://www.oecd.org/innovation/ research/1824983.pdf.

32. Putnam R. (1996). Who Killed Civic America? Prospect, March, pp. 66-72, Retrieved from: https://www.prospectmagazine.co.uk/magazine/ whokilledcivicamerica. 